\title{
Colchicine, fragmented QRS, coronavirus disease 2019, and more
}

Şen et al. from Turkey, in his article, has aimed to overview the drug interactions between colchicine and cardiovascular drugs and has performed a meta-analysis to evaluate the safety profile of colchicine in cardiovascular treatment, which is recently very popular.

Which number is beneficial for heart rate in patients with HFrEF? You will find the answer in this paper by Geng et al. from China.

Saucedo-Orozco et al. from Mexico report on the most extensive series of patients with patent ductus arteriosus cases with infective endarteritis (PDA-IE) studied using echocardiography (and some with cardiac MRI or cardiac CT) in the literature, which should contribute significantly to this field.

A clinical trial by Nichita-Brendea et al. from Romania has compared complete revascularization at the time of primary percutaneous coronary intervention with index hospital admission in patients with multivessel coronary artery disease with ST-elevation myocardial infarction uncomplicated by cardiogenic shock, with very relevant results.

The predictive and prognostic value of $\mathrm{CHA}_{2} \mathrm{DS}_{2}$-VASc score on SYNTAX score and in-hospital mortality in non-ST segment elevation myocardial infarction remains unclear. Akboğa et al. from Turkey has investigated this relationship in their study.

Surgery is considered as a relative contraindication in sarcoma tumor. Is it so? Jiang and Yan give the results of their surgical experiences for cardiac sarcoma with a 1-year follow-up report.

What is the importance of coexistence of fragmented ORS and cardiovascular disease in critically ill patients with coronavirus disease 2019? Two studies from Turkey by Katkat et al. and Özdemir et al. have attempted to analyze these unusual ECG changes and have found unexpected results.

Reducing the cardiotoxic effects of anthracyclines is an important issue in cardio-oncology. A pretreatment strategy is recommended to avoid cardiotoxic effects. Dindaş et al. from Turkey evaluated angiotensin receptor-neprilysin inhibition by sacubitril/valsartan in a pretreatment mice model, with interesting findings.

And many more relevant and compelling case reports, letters, and e-page originals.

I am sure our latest issue will prove to be valuable reading to our readers.

Prof. Dr. Çetin EROL

Editor-in-Chief

Ankara-Turkey

\author{
Address for Correspondence: Prof. Dr. Çetin Erol, \\ Ankara Üniversitesi Tıp Fakültesi, İbn-i Sina Hastanesi, Kardiyoloji Anabilim Dalı, Ankara-Türkiye \\ Phone: +90 3123103333 /27 79 E-mail: ctnerol@yahoo.com \\ (C) Copyright 2021 by Turkish Society of Cardiology - Available online at www.anatoljcardiol.com
}

DOI:10.5152/AnatolJCardiol.2021.11 